\title{
Inorganic carbon acquisition in potentially toxic and non-toxic diatoms: the effect of pH-induced changes in seawater carbonate chemistry
}

\author{
Scarlett Trimborn ${ }^{a}$, , Nina Lundholm ${ }^{b}$, Silke Thoms ${ }^{a}$, Klaus-Uwe Richter ${ }^{a}$, Bernd Krock ${ }^{a}$, \\ Per Juel Hansen ${ }^{b}$ and Björn Rost ${ }^{a}$ \\ aAlfred Wegener Institute for Polar and Marine Research, Am Handelshafen 12, 27570 Bremerhaven, Germany \\ ${ }^{b}$ Marine Biological Laboratory, University of Copenhagen, Strandpromenaden 5, DK-3000 Helsingør, Denmark
}

\author{
Correspondence \\ *Corresponding author, \\ e-mail: scarlett.trimborn@awi.de
}

Received 12 July 2007; revised 21 November 2007

doi: 10.1111/j.1399-3054.2007.01038.x
The effects of $\mathrm{pH}$-induced changes in seawater carbonate chemistry on inorganic carbon $\left(\mathrm{C}_{\mathrm{i}}\right)$ acquisition and domoic acid (DA) production were studied in two potentially toxic diatom species, Pseudo-nitzschia multiseries and Nitzschia navis-varingica, and the non-toxic Stellarima stellaris. In vivo activities of carbonic anhydrase (CA), photosynthetic $\mathrm{O}_{2}$ evolution and $\mathrm{CO}_{2}$ and $\mathrm{HCO}_{3}^{-}$ uptake rates were measured by membrane inlet MS in cells acclimated to low (7.9) and high $\mathrm{pH}$ (8.4 or 8.9). Species-specific differences in the mode of carbon acquisition were found. While extracellular carbonic anhydrase (eCA) activities increased with $\mathrm{pH}$ in $P$. multiseries and $S$. stellaris, N. navis-varingica exhibited low eCA activities independent of $\mathrm{pH}$. Half-saturation concentrations $\left(\mathrm{K}_{1 / 2}\right)$ for photosynthetic $\mathrm{O}_{2}$ evolution, which were highest in S. stellaris and lowest in $P$. multiseries, generally decreased with increasing $\mathrm{pH}$. In terms of carbon source, all species took up both $\mathrm{CO}_{2}$ and $\mathrm{HCO}_{3}^{-}$. $\mathrm{K}_{1 / 2}$ values for inorganic carbon uptake decreased with increasing $\mathrm{pH}$ in two species, while in N. navis-varingica apparent affinities did not change. While the contribution of $\mathrm{HCO}_{3}^{-}$to net fixation was more than $85 \%$ in S. stellaris, it was about $55 \%$ in P. multiseries and only approximately $30 \%$ in N. navis-varingica. The intracellular content of DA increased in P. multiseries and N. navis-varingica with increasing $\mathrm{pH}$. Based on our data, we propose a novel role for eCA acting as $\mathrm{C}_{\mathrm{i}}$-recycling mechanism. With regard to $\mathrm{pH}$-dependence of growth, the ' $\mathrm{HCO}_{3}^{-}$user' S. stellaris was as sensitive as the ' $\mathrm{CO}_{2}$ user' $N$. navis-varingica. The suggested relationship between $\mathrm{DA}$ and carbon acquisition/ $\mathrm{C}_{\mathrm{i}}$ limitation could not be confirmed.

\section{Introduction}

Marine diatoms are key players in the ocean carbon cycle, accounting for at least $40 \%$ of the marine primary production (Nelson et al. 1995). Until recently, the effect of inorganic carbon availability on photosynthesis has been largely ignored in marine phytoplankton ecology,

Abbreviations - $a$, fractional contribution of $\mathrm{HCO}_{3}^{-}$to total $\mathrm{C}_{i}$ uptake; $\mathrm{CA}$, carbonic anhydrase; $\mathrm{CCM}$, carbon-concentrating mechanism; $C_{i}$, inorganic carbon; ' $\mathrm{CO}_{2}$ user', algae predominantly taking up $\mathrm{CO}_{2}$; $\mathrm{DA}$, domoic acid; $\mathrm{DBS}$, dextran-bound sulphonamide (inhibitor for eCA); DIC, dissolved inorganic carbon; eCA, extracellular $\mathrm{CA} ; \varepsilon_{\mathrm{a}}$, fractionation factor between $\mathrm{CO}_{2}$ and $\mathrm{HCO}_{3}^{-} ; \varepsilon_{\mathrm{b}}$, fractionation factor of $\mathrm{HCO}_{3}^{-}$and $\mathrm{CO}_{3}^{2-} ; \varepsilon_{\mathrm{f}}$, intrinsic fractionation factor for Rubis $\mathrm{CO} ; \varepsilon_{\mathrm{p}}$, isotope fractionation during POC formation; $\varepsilon_{5}$, equilibrium discrimination between $\mathrm{CO}_{2}$ and $\mathrm{HCO}_{3}^{-} ;$' $\mathrm{HCO}_{3}^{-}$user', algae predominantly taking up $\mathrm{HCO}_{3}^{-}$; iCA, intracellular $\mathrm{CA}_{;} \mathrm{K}_{1 / 2}$, half-saturation concentration; $\mathrm{L}$, leakage $\left(\mathrm{CO}_{2}\right.$ efflux : gross $C_{i}$ uptake); MIMS, membrane inlet mass spectrometer; POC, particulate organic carbon; PGA, 3-phosphoglyleric acid; RubisCO, ribulose-1,5-bisphosphate carboxylase/ oxygenase; $V_{\max }$ maximum rates (substrate saturated). 
particularly because dissolved inorganic carbon (DIC) is always in excess relative to other nutrients. In seawater, $C_{i}$ is mainly found in the form of $\mathrm{HCO}_{3}^{-}$(approximately $2 \mathrm{mmol} \mathrm{I}^{-1}$ ) but also comprises low and variable concentrations of dissolved $\mathrm{CO}_{2}$ (approximately 5$25 \mathrm{~mol} \mathrm{I}^{-1}$ ). The $\mathrm{pH}$, which reflects the partitioning of the carbon species, is usually about 8.2 in air-equilibrated surface waters. Elevated $\mathrm{pH}$ in ocean surface waters is mainly caused by intense primary production during periods with high concentrations of phytoplankton cells, e.g. towards the end of bloom periods (Hansen 2002). Intense photosynthetic activity can result in $\mathrm{pH}$ values as high as 9 in open marine environments (Hinga 2002) and even up to 10 in coastal lagoons and fjords (Hansen 2002). Rising atmospheric $\mathrm{CO}_{2}$ levels caused by human-induced activities such as fossil fuel burning has affected seawater carbonate chemistry. Present day surface ocean $\mathrm{pH}$ is approximately 0.1 units lower than preindustrial values owing to the uptake of 'anthropogenic' $\mathrm{CO}_{2}$ into the ocean and its subsequent dissociation resulting in an increase of the $\mathrm{H}^{+}$concentration. By the end of this century, it is expected that the seawater $\mathrm{pH}$ will have dropped by 0.4 units relative to preindustrial values (Wolf-Gladrow et al. 1999, Intergovernmental Panel on Climate Change 2007). In view of this ocean acidification as well as variations in $\mathrm{pH}$ during blooms, the role of inorganic carbon $\left(\mathrm{C}_{\mathrm{i}}\right)$ acquisition has received increasing attention in phytoplankton ecology and physiology.

The enzyme ribulose-1,5-bisphosphate carboxylase/ oxygenase (RubisCO) fixes $\mathrm{CO}_{2}$ into organic carbon compounds. Owing to the poor affinity of RubisCO for $\mathrm{CO}_{2}\left(\mathrm{~K}_{\mathrm{M}}\right.$ of $20-70 \mu \mathrm{mol} \mathrm{I}{ }^{-1}$ for eukaryotic phytoplankton, Badger et al. 1998), phytoplankton cells employ carbon-concentrating mechanisms (CCMs) to increase the $\mathrm{CO}_{2}$ concentration at the catalytic site of this enzyme. The operation of a CCM in phytoplankton cells significantly increases the efficiency of carbon fixation, thus reported apparent half-saturation concentrations $\left(\mathrm{K}_{1 / 2}\right)$ values for $\mathrm{CO}_{2}$ in microalgae are $<1-8 \mu \mathrm{mol} \mathrm{I}{ }^{-1}$ (Raven and Johnston 1991).

Modes of CCMs have been found to vary in terms of efficiency as well as regulation between taxonomically different groups of phytoplankton (Giordano et al. 2005). This relates to the extent to which either $\mathrm{CO}_{2}$ or $\mathrm{HCO}_{3}^{-}$, or both carbon sources, are actively transported across the plasmalemma, as well as to the presence and location of carbonic anhydrase (CA). This enzyme accelerates the otherwise slow rate of conversion between $\mathrm{HCO}_{3}^{-}$and $\mathrm{CO}_{2}$. Extracellular carbonic anhydrase (eCA) activity has been suggested to be involved in $\mathrm{HCO}_{3}^{-}$utilization by converting $\mathrm{HCO}_{3}^{-}$to $\mathrm{CO}_{2}$, which is subsequently taken up by cells (Sültemeyer 1998, Elzenga et al. 2000). The physiological role of intracellular carbonic anhydrase (iCA) is still not fully understood, but it is possibly involved in different processes (Badger 2003, Badger and Price 1994, Sültemeyer 1998). Another important, but often neglected, component of a CCM is the capacity of the cell to reduce the loss of accumulated $C_{i}$ by minimizing the $\mathrm{CO}_{2}$ efflux through the cell membrane (Raven and Lucas 1985, Rost et al. 2006a, 2006b).

CCMs contribute to the competitive fitness of phytoplankton species, especially under changing $\mathrm{pH}$ levels. While bloom-forming diatom species operate an efficient and regulated CCM that allows maintenance of high growth rates even under elevated $\mathrm{pH}$ (Rost et al. 2003), slow-growing diatom species may not be able to compensate for decreasing $\mathrm{CO}_{2}$ concentrations under these conditions. Previous studies indicate that diatoms possess highly regulated and efficient CCMs with respect to changes in $\mathrm{CO}_{2}$ supply (Burkhardt et al. 2001, Rost et al. 2003). However, whether these are general characteristics of diatoms have yet to be rigorously tested.

Some diatom species produce the neurotoxic amino acid, domoic acid (DA). Toxic diatoms cause ecological and economic problems because of the accumulation of DA in the marine food web. Understanding toxin production is complicated because both toxic and non-toxic strains of the same species co-exist, and it is currently not clear what induces DA production (Bates et al. 1998). Lundholm et al. (2004) suggested that elevated $\mathrm{pH}$-triggers DA production in different strains of Pseudo-nitzschia. The physiological response of toxic diatoms to changes in $\mathrm{pH}$ is still poorly known, and to date, no study has characterized the CCMs of toxic diatoms. Furthermore, it has not yet been investigated whether the increase of intracellular content of DA is dependent on the $\mathrm{pH}$-dependent changes in carbon acquisition.

The aim of the present study was to investigate the effect of $\mathrm{pH}$ on $\mathrm{C}_{\mathrm{i}}$ acquisition as well as on toxin production in three marine diatom species. Cellular uptake of $\mathrm{CO}_{2}$ and $\mathrm{HCO}_{3}^{-}$during steady-state photosynthesis of the two potentially toxic species Pseudo-nitzschia multiseries (a bloom-forming cosmopolitan species) and Nitzschia navis-varingica (which occurs in coastal marine areas and in marine ponds) as well as the non-toxic Stellarima stellaris (a widely distributed species) was estimated by membrane inlet mass spectrometric (MIMS) measurements. This approach was used to determine substrate preferences for $\mathrm{CO}_{2}$ and $\mathrm{HCO}_{3}^{-}$as well as possible shifts in carbon source and cellular leakage $\left(\mathrm{CO}_{2}\right.$ efflux/gross $\mathrm{C}_{\mathrm{i}}$ uptake) with changing $\mathrm{pH}$. To further characterize the CCM of each species, measurements of iCA and eCA activities were performed by monitoring ${ }^{18} \mathrm{O}$ exchange from doubly labelled ${ }^{13} \mathrm{C}^{18} \mathrm{O}_{2}$. 


\section{Materials and methods}

\section{Culture and experimental conditions}

Stellarima stellaris (isolate from the Sound, Denmark), N. navis-varingica (VHL987) and P. multiseries (OKPm013-2) were grown in dilute batch cultures in sterile-filtered $(0.2 \mu \mathrm{m})$ unbuffered seawater, enriched with nutrients, trace metals and vitamins according to $f / 2$ medium (Guillard and Ryther 1962). Silicate was added to a concentration of $317 \mu \mathrm{mol} \mathrm{I}{ }^{-1}$. Experiments were carried out using a light:dark cycle of 16:8 h at a constant temperature of $15^{\circ} \mathrm{C}$. A photon flux density of $200 \mu \mathrm{mol}$ photons $\mathrm{m}^{-2} \mathrm{~s}^{-1}$ was applied using daylight fluorescence lamps that provided a spectrum similar to that of sunlight. The applied photon flux density ensured that neither growth nor production of DA was light limited (Bates et al. 1998). Each treatment was incubated in triplicate in sterile 2.4-I borosilicate bottles. Gentle rotation of the culture flasks five times a day ensured that the cells were kept in suspension.

The medium used for the experiments was adjusted by addition of $\mathrm{HCl}$ or $\mathrm{NaOH}$ to low $\mathrm{pH}$ (7.9) and high $\mathrm{pH}$ (8.4 for S. stellaris and P. multiseries, and 8.9 for N. navisvaringica) on the National Bureau of Standards (NBS) scale. This corresponds to $\mathrm{CO}_{2}$ concentrations of 31, 9.2 and $2.2 \mu \mathrm{mol} \mathrm{kg}{ }^{-1}$, respectively (Table 1 ). $\mathrm{pH}$ was measured using a pH/ion meter (model pMX 3000/pH; WTW, Weilheim, Germany) that was calibrated (two-point calibration) on a daily basis. Daily or twice-daily dilutions with fresh media ensured that the $\mathrm{pH}$ level remained constant $( \pm 0.05$ units) and that the cells stayed in the midexponential growth phase. High $\mathrm{pH}$ levels were selected based on the upper $\mathrm{pH}$ limits observed in the selected species, ensuring that growth rates were not affected by the $\mathrm{pH}$ levels chosen. Growth rates were about 0.70 day $^{-1}$ in $S$. stellaris, 0.95 day $^{-1}$ in $P$. multiseries and 0.59 day $^{-1}$ in N. navis-varingica. Cell concentrations ranged between 500 and 3000 cells $\mathrm{ml}^{-1}$ for the three species.

\section{Determination of seawater carbonate chemistry}

Alkalinity samples were taken from the filtrate (Whatman GFF filter; approximately $0.6 \mu \mathrm{m}$ ) and stored in

Table 1. Parameters of the seawater carbonate system were calculated from $\mathrm{DIC}, \mathrm{pH}$, silicate, phosphate, temperature and salinity using the CO2Sys program (Lewis and Wallace 1998). Errors denote \pm SD $(n=3)$.

\begin{tabular}{lllll}
\hline $\mathrm{pH}(\mathrm{NBS})$ & $\begin{array}{l}\mathrm{TA} \\
\left(\mu \mathrm{Eq} \mathrm{kg}^{-1}\right)\end{array}$ & $\begin{array}{l}\mathrm{DIC} \\
\left(\mu \mathrm{mol} \mathrm{kg}{ }^{-1}\right)\end{array}$ & $\begin{array}{l}\mathrm{CO}_{2} \\
\left.(\mu \mathrm{mol} \mathrm{kg})^{-1}\right)\end{array}$ & $\begin{array}{l}\mathrm{pCO}_{2} \\
(\mathrm{~Pa})\end{array}$ \\
\hline $7.9( \pm 0.05)$ & $2351 \pm 82$ & $2213 \pm 80$ & $31 \pm 1.1$ & $82.8 \pm 3.0$ \\
$8.4( \pm 0.05)$ & $2651 \pm 94$ & $2240 \pm 84$ & $9.2 \pm 0.3$ & $24.6 \pm 0.9$ \\
$8.9( \pm 0.05)$ & $3115 \pm 78$ & $2171 \pm 60$ & $2.2 \pm 0.1$ & $6.0 \pm 0.2$ \\
\hline
\end{tabular}

300-ml borosilicate flasks at $4{ }^{\circ} \mathrm{C}$ and measured in triplicate by potentiometric titration with an average precision of $8 \mu \mathrm{Eq} \mathrm{kg}^{-1}$ (Brewer et al. 1986). Total alkalinity was calculated from linear Gran Plots (Gran 1952). DIC samples were sterile-filtered $(0.2 \mu \mathrm{m})$ and stored in 13-ml borosilicate flasks free of air bubbles at $4^{\circ} \mathrm{C}$ until they were measured with a total carbon analyzer (Shimadzu TOC-5050A 's-Hertogenbosch, The Netherlands) with an average precision of $17 \mu \mathrm{mol} \mathrm{kg}{ }^{-1}$ in triplicate.

The carbonate system was calculated from alkalinity, DIC, silicate, phosphate, temperature and salinity using the CO2Sys program (Lewis and Wallace 1998). Equilibrium constants of Mehrbach et al. (1973) refitted by Dickson and Millero (1987) were used. The carbonate chemistry was kept constant over the duration of the experiment (Table 1).

\section{Sampling}

After acclimation for at least 7 days, cells were harvested by gentle filtration over an $8-\mu \mathrm{m}$ membrane filter (Isopore; Millipore, Schwalbach/Ts., Germany). Subsequently, the cells were washed with $\mathrm{CO}_{2}$-free $\mathrm{f} / 2$ medium buffered with $50 \mathrm{mmol} \mathrm{I}^{-1}$ HEPES ( $\mathrm{pH}$ 8.0). The samples were then used for determination of carbon $\left(C_{i}\right)$ fluxes and CA activities with the MIMS. Samples for determination of $\mathrm{Chl}$ a concentration were taken after the measurements and stored at $-80^{\circ} \mathrm{C}$. Chl a was subsequently extracted in $10 \mathrm{ml}$ acetone (overnight in darkness at $4^{\circ} \mathrm{C}$ ) and determined with a Turner Designs Fluorometer.

\section{Determination of CA activity}

Activity of eCA and iCA was determined by measuring the loss of ${ }^{18} \mathrm{O}$ from doubly labelled ${ }^{13} \mathrm{C}^{18} \mathrm{O}_{2}$ to water caused by the interconversion of $\mathrm{CO}_{2}$ and $\mathrm{HCO}_{3}^{-}$(Silverman 1982). The determination of CA activity was performed with a sector field multicollector mass spectrometer (Isoprime; GV Instruments, Manchester, UK) through a gas-permeable polytetrafluoroethylene membrane (PTFE, $0.01 \mathrm{~mm}$ ) inlet system. The reaction sequence of ${ }^{18} \mathrm{O}$ loss from initial ${ }^{13} \mathrm{C}^{18} \mathrm{O}^{18} \mathrm{O}(\mathrm{m} / \mathrm{z}=49)$, through the intermediate ${ }^{13} \mathrm{C}^{18} \mathrm{O}^{16} \mathrm{O}(\mathrm{m} / \mathrm{z}=47)$ to the final isotopomer ${ }^{13} \mathrm{C}^{16} \mathrm{O}^{16} \mathrm{O}(\mathrm{m} / \mathrm{z}=45)$ was recorded continuously. The ${ }^{18} \mathrm{O}$ enrichment was calculated as:

$$
\begin{aligned}
{ }^{18} \mathrm{O} \log (\text { enrichment }) & =\log \frac{\left({ }^{13} \mathrm{C}^{18} \mathrm{O}_{2}\right) \times 100}{{ }^{13} \mathrm{CO}_{2}} \\
& =\log \frac{(49) \times 100}{45+47+49}
\end{aligned}
$$


CA measurements were performed in $8 \mathrm{ml} \mathrm{f} / 2$ medium buffered with $50 \mathrm{mmol} \mathrm{I}^{-1}$ HEPES $(\mathrm{pH} 8.0)$ at $15^{\circ} \mathrm{C}$. To avoid interference with light-dependent $C_{i}$ uptake by the cells, all measurements were carried out in the dark. When chemical equilibrium was reached after injection of $1 \mathrm{mmol} \mathrm{I}{ }^{-1} \mathrm{NaH}^{13} \mathrm{C}^{18} \mathrm{O}$, the uncatalysed ${ }^{18} \mathrm{O}$ loss was monitored for about 8 min prior to the addition of cells. eCA activity was calculated from the increasing rate of ${ }^{18} \mathrm{O}$ depletion after addition of the cells (slope $\mathrm{S}_{2}$ ) in comparison with the uncatalysed reaction (slope $S_{1}$ ) and normalized on a Chl a basis (Badger and Price 1989):

$$
U=\frac{\left(S_{2}-S_{1}\right) \times 100}{S_{1} \times \mu g \text { Chl } a}
$$

iCA activity was determined in the presence of $100 \mu \mathrm{mol}$ $\mathrm{I}^{-1}$ dextran-bound sulphonamide (DBS), an inhibitor of eCA. The drop in the log(enrichment) was calculated by extrapolation of $\mathrm{S}_{2}$ back to the time of cell injection $[\Delta$ as defined by Palmqvist et al. (1994)]. Values of $\Delta$ are expressed in arbitrary units per $\mu \mathrm{g} \mathrm{Chl} \mathrm{a.} \mathrm{Chl} \mathrm{a} \mathrm{concen-}$ trations in CA assays ranged from 0.13 to $1.34 \mu \mathrm{g} \mathrm{ml}^{-1}$.

\section{Determination of net photosynthesis, $\mathrm{CO}_{2}$ and $\mathrm{HCO}_{3}^{-}$uptake}

$\mathrm{C}_{\mathrm{i}}$ fluxes were determined during steady-state photosynthesis with the same MIMS as for CA measurements. The method established by Badger et al. (1994) is based on simultaneous measurements of $\mathrm{O}_{2}$ and $\mathrm{CO}_{2}$ during consecutive light and dark intervals. Known amounts of $\mathrm{C}_{\mathrm{i}}$ were added to measure photosynthesis and carbon uptake rates as a function of $\mathrm{CO}_{2}$ and $\mathrm{HCO}_{3}^{-}$or DIC concentrations. Net photosynthesis, $\mathrm{CO}_{2}$ uptake and $\mathrm{HCO}_{3}^{-}$uptake were calculated according to the equations of Badger et al. (1994). All measurements were performed in initially $\mathrm{CO}_{2}$-free $\mathrm{f} / 2$ medium buffered with $50 \mathrm{mmol} \mathrm{I}^{-1} \mathrm{HEPES}(\mathrm{pH} 8.0)$ at $15^{\circ} \mathrm{C}$. DBS was added to the cuvette to a final concentration of $100 \mu \mathrm{mol} \mathrm{I}{ }^{-1}$. Light and dark intervals during the assay lasted $6 \mathrm{~min}$. The incident photon flux density was $300 \mu \mathrm{mol}$ photons $\mathrm{m}^{-2}$ $\mathrm{s}^{-1}$. Further details on the method and calculations are given in Badger et al. (1994) and Rost et al. (2007). Chl a concentrations in the assay ranged from 0.28 to $1.57 \mu \mathrm{g} \mathrm{ml} \mathrm{l}^{-1}$.

\section{Carbon isotope fractionation}

Samples for particulate organic carbon (POC) were filtered onto precombusted $\left(500^{\circ} \mathrm{C}, 12 \mathrm{~h}\right)$ GFF filters (approximately $0.6 \mu \mathrm{m}$ ) and stored in precombusted $\left(500^{\circ} \mathrm{C}, 12 \mathrm{~h}\right)$ Petri dishes at $-20^{\circ} \mathrm{C}$. Prior to analysis,
POC filters were treated with $200 \mu \mathrm{HCl}(0.1 \mathrm{~N})$ to remove all inorganic carbon. POC and related $\delta^{13} \mathrm{C}$ values were subsequently measured in duplicate on an EA mass spectrometer (ANCA-SL 2020; Sercon Ltd, Crewe, UK), with a precision of $\pm 1.5 \mu \mathrm{g} C$ and $\pm 0.5 \%$, respectively. The isotopic composition is reported relative to the PeeDee belemnite standard:

$$
\delta^{13} \mathrm{C}_{\text {Sample }}=\left[\frac{\left({ }^{13} \mathrm{C} /{ }^{12} \mathrm{C}\right)_{\text {Sample }}}{\left({ }^{13} \mathrm{C} /{ }^{12} \mathrm{C}\right)_{\mathrm{PDB}}}-1\right] \times 1000
$$

Isotope fractionation during POC formation $\left(\varepsilon_{\mathrm{p}}\right)$ was calculated relative to the isotopic composition of $\mathrm{CO}_{2}$ in the medium (Freeman and Hayes 1992):

$$
\varepsilon_{\mathrm{p}}=\frac{\delta^{13} \mathrm{C}_{\mathrm{CO}_{2}}-\delta^{13} \mathrm{C}_{\mathrm{POC}}}{1+\frac{\delta^{13} \mathrm{C}_{\mathrm{POC}}}{1000}}
$$

To determine isotopic composition of DIC $\left(\delta^{13} \mathrm{C}_{\mathrm{DIC}}\right)$, samples were sterile filtered $(0.2 \mu \mathrm{m})$, fixed with $\mathrm{HgCl}_{2}$ (approximately $140 \mathrm{mg} \mathrm{I}^{-1}$ final concentration) and stored at $4^{\circ} \mathrm{C}$. Measurements of $\delta^{13} \mathrm{C}_{\text {DIC }}$ were performed with a Finnegan mass spectrometer (MAT 252) at a precision of $\delta^{13} \mathrm{C}= \pm 0.05 \%$. The isotopic composition of $\mathrm{CO}_{2}\left(\delta^{13} \mathrm{C}_{\mathrm{CO} 2}\right)$ was calculated from $\delta{ }^{13} \mathrm{C}_{\mathrm{DIC}}$, making use of a mass balance relation (Zeebe and Wolf-Gladrow 2001):

$$
\begin{aligned}
& \delta^{13} \mathrm{C}_{\mathrm{HCO}_{3}^{-}} \\
& =\frac{\delta^{13} \mathrm{C}_{\mathrm{DIC}}[\mathrm{DIC}]-\left(\varepsilon_{\mathrm{a}}\left[\mathrm{CO}_{2}\right]+\varepsilon_{\mathrm{b}}\left[\mathrm{CO}_{3}^{2-}\right]\right)}{\left(1+\varepsilon_{\mathrm{a}} \times 10^{-3}\right)\left[\mathrm{CO}_{2}\right]+\left[\mathrm{HCO}_{3}^{-}\right]+\left(1+\varepsilon_{\mathrm{b}} \times 10^{-3}\right)\left[\mathrm{CO}_{3}^{2-}\right]}
\end{aligned}
$$

$$
\delta^{13} \mathrm{C}_{\mathrm{CO}_{2}}=\delta^{13} \mathrm{C}_{\mathrm{HCO}_{3}^{-}}\left(1+\varepsilon_{\mathrm{a}} \times 10^{-3}\right)+\varepsilon_{\mathrm{a}}
$$

Temperature-dependent fractionation factors between $\mathrm{CO}_{2}$ and $\mathrm{HCO}_{3}^{-}\left(\varepsilon_{\mathrm{a}}\right)$ as well as between $\mathrm{HCO}_{3}^{-}$and $\mathrm{CO}_{3}{ }^{2-}\left(\varepsilon_{\mathrm{b}}\right)$ are given by Mook (1986) and Zhang et al. (1995), respectively.

\section{Toxin analyses}

The samples for toxin analyses $(600$ or $1000 \mathrm{ml}$ ) were filtered through a $3-\mu \mathrm{m}$ polycarbonate filter, which was never allowed to dry out. The residue on the filter was rinsed with fresh culture medium and subsequently transferred to a falcon tube and adjusted to a final volume 
of $4 \mathrm{ml}$. Initial measurements on the filtered medium showed no DA (i.e. extracellular DA) in any of the treatments and consequently filtered medium was not subsequently measured. Cell counts were used for determination of toxin content per cell. Until further analysis, samples were stored at $-20^{\circ} \mathrm{C}$.

For preparation of the samples, $4 \mathrm{ml}$ of frozen material were thawed and subsequently centrifuged at $4^{\circ} \mathrm{C}$ for $15 \mathrm{~min}$ at $2100 \mathrm{~g}$. Because diatoms partially break during freezing and thawing cycles and cell content leaks into the medium, DA had to be determined in cell pellets and supernatant. Five hundred microlitres of the supernatant was centrifuged (Eppendorf 5415 R; Eppendorf, Hamburg, Germany) for $30 \mathrm{~s}$ at $800 \mathrm{~g}$ through a spin filter (pore size $0.45 \mu \mathrm{m}$, Millipore-Ultrafree, Eschborn, Germany) and frozen at $-20^{\circ} \mathrm{C}$ until LC-MS/MS analysis for measurement of DA in the cell-free fraction. Cell pellets were resuspended in $0.5 \mathrm{ml}$ water-methanol $(1: 1 \mathrm{v} / \mathrm{v})$, transferred to FastPrep tubes containing $0.9 \mathrm{~g}$ of lysing matrix D (Thermo Savant, Illkirch, France) and subsequently homogenized by reciprocal shaking at maximum speed for $45 \mathrm{~s}$ in a Bio101 FastPrep instrument (Thermo Savant). After homogenization, samples were centrifuged at $16100 \mathrm{~g}$ at $4^{\circ} \mathrm{C}$ for $15 \mathrm{~min}$. Supernatants were removed and centrifuged for $30 \mathrm{~s}$ at $800 \mathrm{~g}$ through a spin filter and frozen at $-20^{\circ} \mathrm{C}$ until LC-MS/MS analysis of DA in the cellular fraction.

Mass spectrometric measurements were performed on an ABI-SCIEX-4000 Q Trap, triple quadrupole mass spectrometer equipped with a TurboSpray ${ }^{\circledR}$ interface coupled to an Agilent model 1100 LC. Analyses for DA were performed in triplicate. The analytical column $(250 \times 4.6 \mathrm{~mm})$ was packed with $5 \mu \mathrm{m}$ Luna C18 (Phenomenex, Aschaffenburg, Germany) and maintained at $25^{\circ} \mathrm{C}$. The flow rate was $1.0 \mathrm{ml} \mathrm{min}{ }^{-1}$ and gradient elution was performed with two eluents, where eluent $\mathrm{A}$ was $2 \mathrm{mmol} \mathrm{\textrm {I } ^ { - 1 }}$ ammonium formate and $50 \mathrm{mmol} \mathrm{I}^{-1}$ formic acid in water and eluent $\mathrm{B}$ was $2 \mathrm{mmol} \mathrm{I}^{-1}$ ammonium formate and $50 \mathrm{mmol} \mathrm{I}^{-1}$ formic acid in acetonitrile/water $(95: 5 \mathrm{v} / \mathrm{v})$. The gradient was as follows: 9 min column equilibration with $87 \% \mathrm{~A}$, 2 min isocratic with $87 \% \mathrm{~A}$, then linear gradient until $10 \mathrm{~min}$ to $50 \% \mathrm{~A}$, then until $11 \mathrm{~min}$ return to initial conditions $87 \%$ A. Total run time was $20 \mathrm{~min}$. Five microlitres of sample were injected.

Measurements were carried out in the multiple reaction monitoring (MRM) mode by selecting the following transitions for DA (precursor ion $>$ fragment ion): $\mathrm{m} / \mathrm{z}$ $312>266$ (quantifier) and $\mathrm{m} / \mathrm{z} \quad 312>161$ (qualifier). Dwell times of $150 \mathrm{~ms}$ were used for each transition. For these studies, the following source parameters were used - curtain gas: 25 psi, temperature: $600^{\circ} \mathrm{C}$, ion-spray voltage: $5500 \mathrm{~V}$, nebulizer gas: 55 psi, auxiliary gas: 70 psi, interface heater: on, and declustering potential: $66 \mathrm{~V}$.

\section{Results}

\section{Photosynthesis and $C_{i}$ fluxes}

During steady-state photosynthesis, $\mathrm{CO}_{2}$ and $\mathrm{HCO}_{3}^{-}$ were taken up simultaneously by all species (Table 2). Maximum rates $\left(\mathrm{V}_{\max }\right)$ and half-saturation concentrations $\left(\mathrm{K}_{1 / 2}\right)$ were obtained from a Michaelis-Menten fit to the data and are summarized in Table 2. The acclimation of a species to low and high $\mathrm{pH}$ had no effect on the $\mathrm{V}_{\max }$ of photosynthetic $\mathrm{O}_{2}$ evolution in the assay, i.e. $\mathrm{V}_{\max }$ remained constant (Table 2). In comparison, P. multiseries exhibited the highest photosynthetic rates on a $\mathrm{Chl}$ a basis. In all investigated species, $\mathrm{K}_{1 / 2}$ values for photosynthetic $\mathrm{O}_{2}$ evolution decreased with rising $\mathrm{pH}$ (Table 2). Highest $\mathrm{K}_{1 / 2}$ values were recorded in $S$. stellaris and lowest in $P$. multiseries. In all three species, $\mathrm{K}_{1 / 2}$ $\left(\mathrm{CO}_{2}\right)$ values for photosynthesis were about one order of

Table 2. $\mathrm{K}_{1 / 2}$ and $\mathrm{V}_{\max }$ of photosynthesis, net $\mathrm{CO}_{2}$ uptake and $\mathrm{HCO}_{3}^{-}$uptake for Stellarima stellaris, Pseudo-nitzschia multiseries and Nitzschia navisvaringica acclimated to low and high $\mathrm{pH}$. Kinetic parameters were calculated from a Michaelis-Menten fit to the combined data of several independent measurements. Values for $\mathrm{K}_{1 / 2}$ and $\mathrm{V}_{\max }$ are given in $\mu \mathrm{mol} \mathrm{I}^{-1}$ and $\mu \mathrm{mol}(\mathrm{mg} \mathrm{Chl} \mathrm{a})^{-1} \mathrm{~h}^{-1}$, respectively. Error bars denote $\pm \mathrm{SD}$.

\begin{tabular}{|c|c|c|c|c|c|c|c|c|}
\hline \multirow[b]{2}{*}{$\mathrm{pH}$ (NBS) } & \multicolumn{4}{|c|}{ Photosynthesis } & \multicolumn{2}{|c|}{ Net $\mathrm{CO}_{2}$ uptake } & \multicolumn{2}{|l|}{$\mathrm{HCO}_{3}^{-}$uptake } \\
\hline & $\mathrm{K}_{1 / 2}\left(\mathrm{CO}_{2}\right)$ & $\mathrm{V}_{\max }\left(\mathrm{CO}_{2}\right)$ & $\mathrm{K}_{1 / 2}(\mathrm{DIC})$ & $V_{\max }(D I C)$ & $\mathrm{K}_{1 / 2}\left(\mathrm{CO}_{2}\right)$ & $\mathrm{V}_{\max }\left(\mathrm{CO}_{2}\right)$ & $\mathrm{K}_{1 / 2}\left(\mathrm{HCO}_{3}^{-}\right)$ & $\mathrm{V}_{\max }\left(\mathrm{HCO}_{3}^{-}\right)$ \\
\hline \multicolumn{9}{|l|}{ S. stellaris } \\
\hline 7.9 & $7.4 \pm 1.7$ & $258 \pm 17$ & $572 \pm 133$ & $258 \pm 17$ & - & $40 \pm 29$ & $329 \pm 150$ & $219 \pm 23$ \\
\hline 8.4 & $4.0 \pm 0.5$ & $262 \pm 9$ & $304 \pm 41$ & $264 \pm 10$ & - & $8.6 \pm 5.3$ & $227 \pm 34$ & $254 \pm 9$ \\
\hline \multicolumn{9}{|c|}{ P. multiseries } \\
\hline 7.9 & $3.5 \pm 0.5$ & $363 \pm 20$ & $327 \pm 57$ & $368 \pm 22$ & $4.6 \pm 0.6$ & $175 \pm 10$ & $241 \pm 49$ & $190 \pm 14$ \\
\hline 8.4 & $2.2 \pm 0.3$ & $354 \pm 15$ & $223 \pm 39$ & $369 \pm 18$ & $2.3 \pm 0.3$ & $148 \pm 8$ & $186 \pm 63$ & $218 \pm 15$ \\
\hline \multicolumn{9}{|c|}{ N. navis-varingica } \\
\hline 7.9 & $4.6 \pm 0.7$ & $262 \pm 10$ & $494 \pm 67$ & $261 \pm 9$ & $6.0 \pm 1.0$ & $221 \pm 10$ & - & $42 \pm 4$ \\
\hline 8.9 & $3.1 \pm 0.9$ & $287 \pm 19$ & $301 \pm 84$ & $290 \pm 18$ & $6.6 \pm 1.2$ & $203 \pm 11$ & - & $89 \pm 8$ \\
\hline
\end{tabular}


magnitude lower than the $\mathrm{K}_{\mathrm{M}}\left(\mathrm{CO}_{2}\right)$ values known for RubisCO in diatoms (approximately 30-40 $\mu \mathrm{mol}$ $\mathrm{CO}_{2} \mathrm{I}^{-1}$; Badger et al. 1998).

In terms of $\mathrm{CO}_{2}$ uptake, the $\mathrm{K}_{1 / 2}$ values for $\mathrm{N}$. navisvaringica and $P$. multiseries were generally between 4 and $7 \mu \mathrm{mol} \mathrm{I}^{-1}$, only in $P$. multiseries the acclimation to high $\mathrm{pH}$ induced higher affinities (Table 2). The $\mathrm{V}_{\max }$ for net $\mathrm{CO}_{2}$ uptake for $N$. navis-varingica and $P$. multiseries ranged between 148 and $221 \mu \mathrm{mol}(\mathrm{mg} \mathrm{Chl} \mathrm{a})^{-1} \mathrm{~h}^{-1}$. In S. stellaris, net $\mathrm{CO}_{2}$ uptake was very low and hence no $\mathrm{K}_{1 / 2}$ values could be estimated. Regarding the $\mathrm{HCO}_{3}^{-}$ uptake, $\mathrm{K}_{1 / 2}$ values in $P$. multiseries and in $S$. stellaris were generally $<330 \mu^{m o l ~ I}{ }^{-1}$ and decreased when acclimated to high $\mathrm{pH}$. In S. stellaris, the $\mathrm{V}_{\max }$ of $\mathrm{HCO}_{3}^{-}$ uptake was slightly higher than that for $P$. multiseries. For N. navis-varingica, the $\mathrm{HCO}_{3}^{-}$uptake was low and could not be described by Michaelis-Menten kinetics.

Using the uptake kinetics obtained in the assay, the contribution of $\mathrm{HCO}_{3}^{-}$uptake relative to carbon fixation for the conditions of the respective incubations was estimated (Fig. 1). The preference for $\mathrm{HCO}_{3}^{-}$uptake strongly increased in $\mathrm{N}$. navis-varingica with rising $\mathrm{pH}$, while the different $\mathrm{pH}$ acclimations yielded similar ratios in P. multiseries and S. stellaris. With values larger than $85 \%$, the preference for $\mathrm{HCO}_{3}^{-}$is very high in S. stellaris, whereas $P$. multiseries reached values of approximately $55 \%$. In N. navis-varingica, the contribution of $\mathrm{HCO}_{3}^{-}$ uptake relative to net fixation accounted for at most approximately $30 \%$ under high $\mathrm{pH}$, reflecting a strong preference for $\mathrm{CO}_{2}$.

\section{eCA and iCA activity}

Activity of eCA was high in $P$. multiseries and $S$. stellaris and increased with elevated $\mathrm{pH}$ (Fig. 2A). In N. navis-

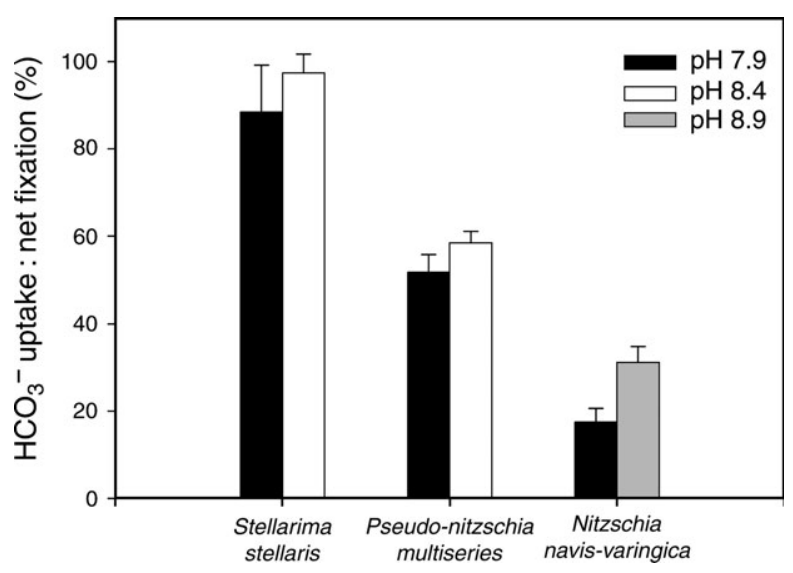

Fig. 1. Ratios of $\mathrm{HCO}_{3}^{-}$uptake to net photosynthesis of cells acclimated to different $\mathrm{pH}$ levels. Ratios from MIMS measurements were based on the rates obtained at $C_{i}$ concentrations of about $2 \mathrm{mmol} \mathrm{I}^{-1}$.
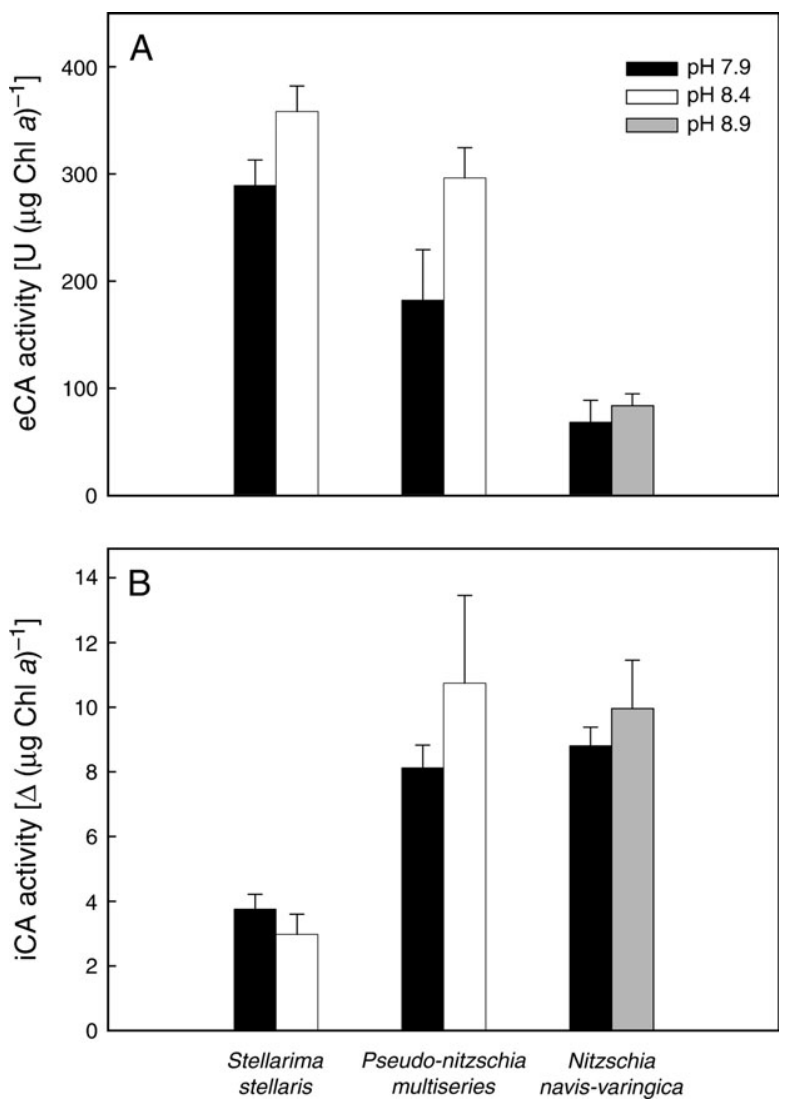

Fig. 2. Chl a-specific activities of (A) eCA and (B) iCA activities from cells acclimated to low and high $\mathrm{pH}$. Values represent the means of triplicate incubations ( \pm SD).

varingica, eCA activities were low and remained constant independent of the $\mathrm{pH}$. The activities of iCA remained constant in all investigated species, independent of the $\mathrm{pH}$ of the acclimation (Fig. 2B).

\section{Carbon isotope fractionation and leakage}

Carbon isotope fractionation decreased with rising $\mathrm{pH}$ in all investigated species (Fig. 3). The strongest reduction in $\varepsilon_{\mathrm{p}}$ was observed in N. navis-varingica, with $\varepsilon_{\mathrm{p}}$ being $9.8 \%$ under low $\mathrm{pH}$ and $3.7 \%$ at high $\mathrm{pH}$. S. stellaris obtained highest fractionation values in comparison with the two other species, its $\varepsilon_{\mathrm{p}}$ ranged between 11.5 and $14.4 \%$.

The leakage of cells, i.e. the proportion of $C_{i}$ efflux compared with gross $C_{i}$ uptake, was estimated by MIMS through the $\mathrm{CO}_{2}$ efflux recorded immediately after the light had been turned off (Badger et al. 1994). For all species, leakage was highest at the lowest $\mathrm{CO}_{2}$ concentrations and levelled off towards higher $\mathrm{CO}_{2}$ concentrations in the assay (Fig. 4). With increasing $\mathrm{pH}$, leakage appeared to decrease mainly in $\mathrm{N}$. navis-varingica. 


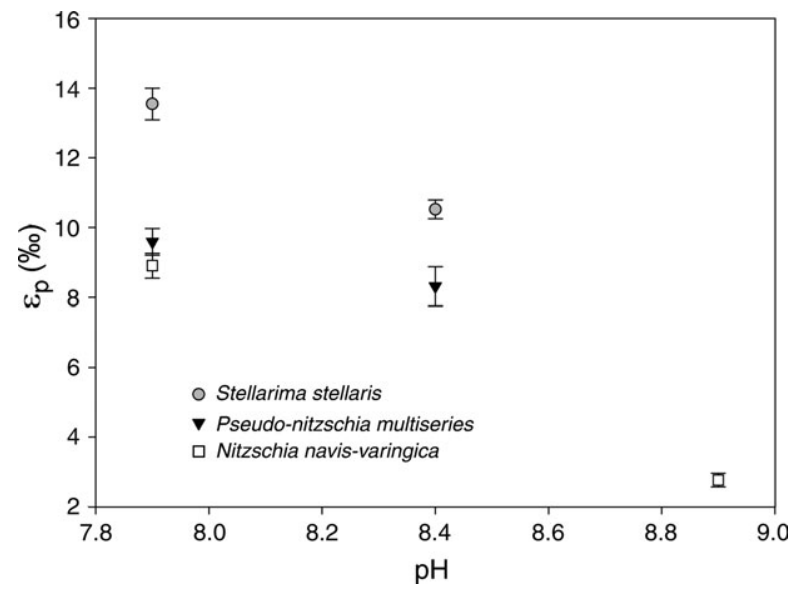

Fig. 3. Isotope fractionation $\left(\varepsilon_{\mathrm{p}}\right)$ as a function of $\mathrm{pH}$, calculated from the ${ }^{13} \mathrm{C}_{\mathrm{CO} 2}$ and ${ }^{13} \mathrm{C}_{\mathrm{POC}}$ in the respective acclimations of each species. Error bars denote $\pm S D(n=3)$.

\section{DA production}

The content of DA per cell differed with $\mathrm{pH}$, both for $P$. multiseries and for $\mathrm{N}$. navis-varingica. Increasing $\mathrm{pH}$ resulted in increasing content of DA (Table 3). The differences were, however, only significant between the $\mathrm{pH}$ levels for $P$. multiseries (Student's $t$-test, $P<0.01$ ). No DA was detected in $S$. stellaris at any of the $\mathrm{pH}$ levels.

\section{Discussion}

The application of MIMS techniques such as the estimation of $\mathrm{CA}$ activities and $\mathrm{C}_{\mathrm{i}}$ fluxes, in combination with analyses of ${ }^{13} \mathrm{C}$ fractionation, allowed detailed characterization of the CCM in each species. Acclimations to low and high $\mathrm{pH}$ were performed in unbuffered seawater with low cell densities to simulate natural conditions as closely as possible. High affinities for $C_{i}$ were observed in all investigated species, indicating the operation of a CCM (Table 2). All species upregulated their CCM activity when acclimated to high $\mathrm{pH}$. Despite these similarities, strong species-specific differences in the modes of carbon acquisition existed.

\section{Photosynthetic $\mathrm{O}_{2}$ evolution}

Apparent $\mathrm{K}_{1 / 2}\left(\mathrm{CO}_{2}\right)$ for photosynthesis lower than $\mathrm{K}_{\mathrm{M}}$ $\left(\mathrm{CO}_{2}\right)$ of RubisCO provides evidence for the operation of a CCM (Badger et al. 1998). In our experiments, $\mathrm{K}_{1 / 2}\left(\mathrm{CO}_{2}\right)$ values for photosynthesis were low in all investigated species, ranging from 2.2 to $7.4 \mu \mathrm{mol} \mathrm{CO}_{2}$ (Table 2). These values are about an order of magnitude lower than known $\mathrm{K}_{\mathrm{M}}\left(\mathrm{CO}_{2}\right)$ values for RubisCO in diatoms (31-36 $\mu \mathrm{mol} \mathrm{CO} \mathrm{Cl}^{-1}$ in two strains of Cylindrotheca sp.
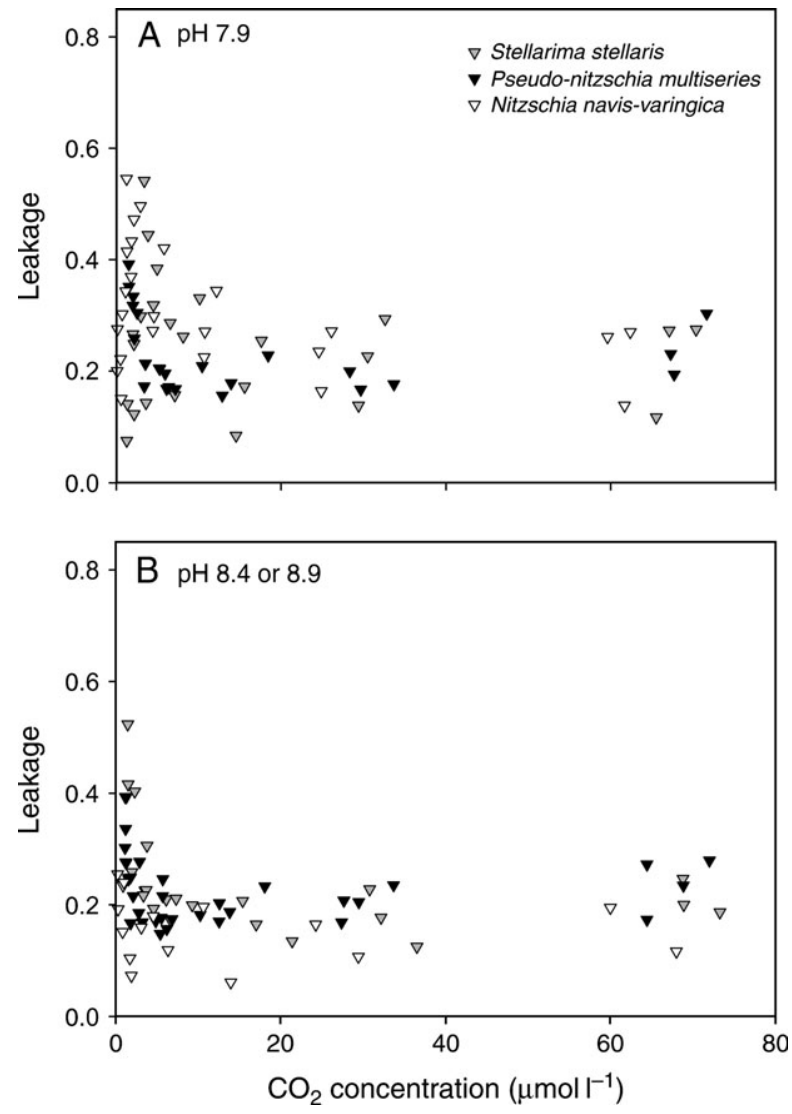

Fig. 4. Leakage of the cells, i.e. the proportion of $C_{i}$ efflux relative to gross $\mathrm{C}_{i}$ uptake, as a function of the $\mathrm{CO}_{2}$ concentration in the $\mathrm{C}_{i}$ flux assay from each species acclimated to (A) low and (B) high $\mathrm{pH}$.

and $41 \mu \mathrm{mol} \mathrm{CO} \mathrm{CO}_{2} \mathrm{I}^{-1}$ in Phaeodactylum tricornutum; Badger et al. 1998), indicating that the investigated species possessed highly efficient CCMs. All three species had upregulated their carbon acquisition with decreasing $\mathrm{CO}_{2}$ supply (Table 2). The observed affinities are comparable with previous findings obtained with MIMS techniques in marine diatoms (Burkhardt et al. 2001, Rost et al. 2003). By measuring the photosynthetic $\mathrm{O}_{2}$ evolution upon the addition of varying $\mathrm{C}_{\mathrm{i}}$ concentrations and assuming equilibrium concentrations for $\mathrm{CO}_{2}$,

Table 3. The intracellular content of DA in the investigated diatoms acclimated to different $\mathrm{pH}$ levels. Values represent the mean of triplicates \pm SD.

\begin{tabular}{lccccc}
\hline \multicolumn{4}{c}{$\begin{array}{l}\text { Nitzschia } \\
\text { navis-varingica }\end{array}$} & \multicolumn{4}{l}{$\begin{array}{l}\text { Pseudo-nitzschia } \\
\text { multiseries }\end{array}$} \\
\hline $\mathrm{pH}$ & 7.9 & 8.9 & 7.9 & 8.4 & 8.9 \\
$\begin{array}{l}\text { Intracellular } \\
\text { toxin content } \\
(\mathrm{pg} \mathrm{cell}\end{array}$ & $158 \pm 15)$ & $213 \pm 28$ & $1.9 \pm 0.3$ & $4.2 \pm 0.4$ & $140 \pm 8$ \\
\hline
\end{tabular}


$\mathrm{K}_{1 / 2}\left(\mathrm{CO}_{2}\right)$ values for photosynthetic $\mathrm{O}_{2}$ evolution have been estimated (Burns and Beardall 1987, Colman and Rotatore 1995, Mitchell and Beardall 1996). Mitchell and Beardall (1996) calculated the $\mathrm{K}_{1 / 2}\left(\mathrm{CO}_{2}\right)$ value to be approximately $1.09 \mu \mathrm{mol} \mathrm{I}^{-1}$ at $\mathrm{pH} 7.5$ in the sea-ice diatom Nitzschia frigida. Colman and Rotatore (1995) demonstrated $\mathrm{K}_{1 / 2}\left(\mathrm{CO}_{2}\right)$ values of $1.44 \mu \mathrm{mol} \mathrm{I}{ }^{-1}$ for Cyclotella sp. and $4.01 \mu \mathrm{mol} \mathrm{I}{ }^{-1}$ for P. tricornutum. For the latter species, Burns and Beardall (1987) obtained an even lower $\mathrm{K}_{1 / 2}\left(\mathrm{CO}_{2}\right)$ value of $0.53 \mu \mathrm{mol} \mathrm{CO}_{2} \mathrm{I}^{-1}$. In summary, the $\mathrm{CO}_{2} / \mathrm{pH}$-induced changes in apparent $\mathrm{C}_{\mathrm{i}}$ affinities and the generally low $\mathrm{K}_{1 / 2}\left(\mathrm{CO}_{2}\right)$ for photosynthesis indicate highly efficient and regulated CCMs in the investigated species.

\section{Carbon sources and uptake kinetics}

To understand why a certain species appears to have a more or less efficient carbon acquisition, in other words different abilities to reach $\mathrm{C}_{\mathrm{i}}$-saturated rates in photosynthesis, the different components of the CCM must be characterized. In the present study, $\mathrm{CO}_{2}$ and $\mathrm{HCO}_{3}^{-}$rates were estimated following the method of Badger et al. (1994). This approach has the advantage that it also allows determination of carbon uptake kinetics during steady-state photosynthesis. While several studies demonstrated that simultaneous uptake of $\mathrm{CO}_{2}$ and $\mathrm{HCO}_{3}^{-}$ occurs in marine diatoms (e.g. Burns and Beardall 1987, Korb et al. 1997, Rotatore et al. 1995, Tortell and Morel 2002), a finding that is consistent with our results, little information exists on uptake kinetics for individual carbon sources (e.g. Burkhardt et al. 2001, Rost et al. 2003, Rost et al. 2006a).

The efficiency of a CCM is strongly depending on the characteristics of the $\mathrm{C}_{\mathrm{i}}$ uptake systems. Higher transport rates for $\mathrm{CO}_{2}$ and/or $\mathrm{HCO}_{3}^{-}$can be achieved in two ways: either by increasing the affinities for the respective $C_{i}$ species through a higher substrate-binding capacity (e.g. Amoroso et al. 1998, Matsuda and Colman 1995, Palmqvist et al. 1994) or by an increase in the number of transporters (e.g. Burkhardt et al. 2001, Rost et al. 2003). According to our results, species responded differently to $\mathrm{pH}$-induced changes in carbonate chemistry. P. multiseries used $\mathrm{CO}_{2}$ and $\mathrm{HCO}_{3}^{-}$in equal quantities, which did not change with $\mathrm{pH}$ (Fig. 1). This is the result of an increased substrate affinity of the $\mathrm{CO}_{2}$ uptake system, which compensated for the lower $\mathrm{CO}_{2}$ availability at high $\mathrm{pH}$ (Fig. 1). N. navis-varingica was characterized by a strong preference for $\mathrm{CO}_{2}$ (' $\mathrm{CO}_{2}$ user'), although the contribution of $\mathrm{HCO}_{3}^{-}$uptake relative to net fixation increased with rising $\mathrm{pH}$ (Table 2). The latter might be because of a larger number of $\mathrm{HCO}_{3}^{-}$trans- porters when acclimated to high $\mathrm{pH}$ (Table 2). S. stellaris showed a strong preference for $\mathrm{HCO}_{3}^{-}\left(\mathrm{HCO}_{3}^{-}\right.$user') irrespective of the acclimation $\mathrm{pH}$ (Fig. 1). This observation is consistent with constitutively expressed $C_{i}$ transport systems (Table 2). The large differences in preference for $\mathrm{C}_{\mathrm{i}}$ sources in the group of diatoms are in agreement with those of Burkhardt et al. (2001) who showed that Thalassiosira weissflogii exhibited a much higher proportion of $\mathrm{HCO}_{3}^{-}$uptake relative to total $\mathrm{C}_{\mathrm{i}}$ uptake compared with $P$. tricornutum, the latter preferring $\mathrm{CO}_{2}$ even at the highest $\mathrm{pH}$ level. Rost et al. (2003) showed an increasing contribution of $\mathrm{HCO}_{3}^{-}$to total $\mathrm{C}_{\mathrm{i}}$ uptake with decreasing $\mathrm{CO}_{2}$ concentrations as a consequence of both an increasing number of $\mathrm{HCO}_{3}^{-}$transport components and the induction of high-affinity $\mathrm{C}_{\mathrm{i}}$ uptake systems. Hence, based on our data and on previous investigations, marine diatoms appear to strongly differ in terms of their preferred $C_{i}$ source and the regulation of its uptake.

\section{CA activity and its dependence on the carbon source}

The enzyme CA plays an important role in carbon acquisition by accelerating the otherwise slow interconversion of $\mathrm{CO}_{2}$ and $\mathrm{HCO}_{3}^{-}$, both inside the cell and at the cell surface. The activities of eCA strongly differed between species in our investigation (Fig. 2A), being highest with $360 \cup(\mu \mathrm{g} \mathrm{Chl} \mathrm{a})^{-1}$ in S. stellaris and lowest with $80 \cup(\mu \mathrm{g} \mathrm{Chl} \mathrm{a})^{-1}$ in N. navis-varingica. In other words, these values correspond to an enhancement in the interconversion between $\mathrm{HCO}_{3}^{-}$and $\mathrm{CO}_{2}$ relative to the uncatalysed rate by 360 and $80 \%$ per $\mu \mathrm{g} \mathrm{Chl}$ a, respectively. These activities are within the same range as those reported in Burkhardt et al. (2001) and Rost et al. (2003) [note that activities in these studies were erroneously stated as (mg Chl a) $)^{-1}$ instead of $(\mu \mathrm{g} \mathrm{Chl} \mathrm{a})^{-1}$ ]. Mitchell and Beardall (1996) used a potentiometric approach to estimate CA activities (Wilbur and Anderson 1948) in N. frigida. They measured low eCA activities of $0.123(\mu \mathrm{g} \mathrm{Chl} \mathrm{a})^{-1}$ Wilbur-Anderson units, which corresponds to an enhancement in the rate constants of only approximately $12 \%$ per $\mu \mathrm{g} \mathrm{Chl}$ a relative to the uncatalysed rate. According to our results and those of Mitchell and Beardall (1996), we conclude that eCA plays only a minor role in carbon acquisition in the genus Nitzschia.

The induction of eCA activity was found to be $\mathrm{pH}$ dependent both in laboratory culture experiments (Sültemeyer 1998, Burkhardt et al. 2001, Badger 2003, Rost et al. 2003) and in field experiments (Berman-Frank et al. 1994, Tortell et al. 2006). It is a common notion that eCA is involved in indirect $\mathrm{HCO}_{3}^{-}$utilization by converting $\mathrm{HCO}_{3}^{-}$to $\mathrm{CO}_{2}$, which could then be actively 
transported through the plasma membrane and subsequently used for photosynthesis (Elzenga et al. 2000, Sültemeyer 1998, Tortell et al. 2006). It should be emphasized here that high eCA activities would provide an advantage especially for large cells because large phytoplankton are more prone to $\mathrm{CO}_{2}$ shortage in their diffusive boundary layer (Wolf-Gladrow and Riebesell 1997). Such a function of eCA in supplying $\mathrm{CO}_{2}$ from the large $\mathrm{HCO}_{3}^{-}$pool would, however, not apply at high $\mathrm{pH}$ because the equilibrium is strongly on the side of $\mathrm{HCO}_{3}^{-}$.

In the present study, the investigated diatoms are rather large with volumes of $1030 \mu \mathrm{m}^{3}$ for $P$. multiseries, $4350{\mu \mathrm{m}^{3}}^{3}$ for $N$. navis-varingica and $7720 \mu \mathrm{m}^{3}$ for S. stellaris. Although the highest level of eCA activity was found under high $\mathrm{pH}$ in the largest diatom species S. stellaris (Fig. 2A), this species showed a strong preference for $\mathrm{HCO}_{3}^{-}$uptake and not for $\mathrm{CO}_{2}$ uptake (Fig. 1). Hence, the common notion that eCA supplies $\mathrm{CO}_{2}$ to the uptake systems is called into question in this situation. Here, we propose a mechanism that acts as a $\mathrm{C}_{\mathrm{i}}$-recycling mechanism at high $\mathrm{pH}$ in ' $\mathrm{HCO}_{3}^{-}$user' (Fig. 5A), i.e. $\mathrm{CO}_{2}$ leaking out of the cell would be converted by eCA to $\mathrm{HCO}_{3}^{-}$and subsequently taken up through $\mathrm{HCO}_{3}^{-}$ transporters. Such a mechanism would be most efficient when the CA-mediated conversion is localized to the periplasmic space, i.e. in close vicinity to the $\mathrm{HCO}_{3}^{-}$ transporter. It can be hypothesized that the $\mathrm{HCO}_{3}^{-}$ transport process is linked to the eCA activity. Support for this idea comes from red blood cells where a plasma membrance $\mathrm{HCO}_{3}^{-} / \mathrm{Cl}^{-}$transporter physically binds a CAll protein (Sterling et al. 2001). In contrast to ' $\mathrm{HCO}_{3}^{-}$ users' like $S$. stellaris, the $\mathrm{CO}_{2}$ user N. navis-varingica was characterized by low levels of eCA even under high $\mathrm{pH}$ (Fig. 2A). Because of rather low eCA activities, $\mathrm{CO}_{2}$ leaking out of the cell is prevented from fast conversion to $\mathrm{HCO}_{3}^{-}$, and a disequilibrium at the cell surface persists (Fig. 5B). Elevated $\mathrm{CO}_{2}$ in turn increases the probability that the $\mathrm{CO}_{2}$ is transported back into the cell through $\mathrm{CO}_{2}$ transport systems. We therefore suggest that low or absent eCA activities in $\mathrm{CO}_{2}$ users allow for efficient $\mathrm{CO}_{2}$ recycling at high $\mathrm{pH}$ (Fig. 5B).

The proposed $\mathrm{C}_{\mathrm{i}}$-recycling mechanisms for $\mathrm{CO}_{2}$ and $\mathrm{HCO}_{3}^{-}$users at elevated $\mathrm{pH}$ would explain results from previous studies, i.e. the correlation of high eCA activity and $\mathrm{HCO}_{3}^{-}$uptake and the lack of eCA in $\mathrm{CO}_{2}$ users. Burkhardt et al. (2001) observed high eCA activities and high $\mathrm{HCO}_{3}^{-}$uptake rates in $T$. weissflogii, while P. tricornutum showed a preference for $\mathrm{CO}_{2}$ and eCA activities were low. Skeletonema costatum combined both extremes, i.e. high eCA activities and predominant $\mathrm{HCO}_{3}^{-}$uptake under high $\mathrm{pH}$, whereas eCA was lacking at low $\mathrm{pH}$ accompanied by a strong preference for $\mathrm{CO}_{2}$ (Rost et al. 2003). We consequently conclude, based on
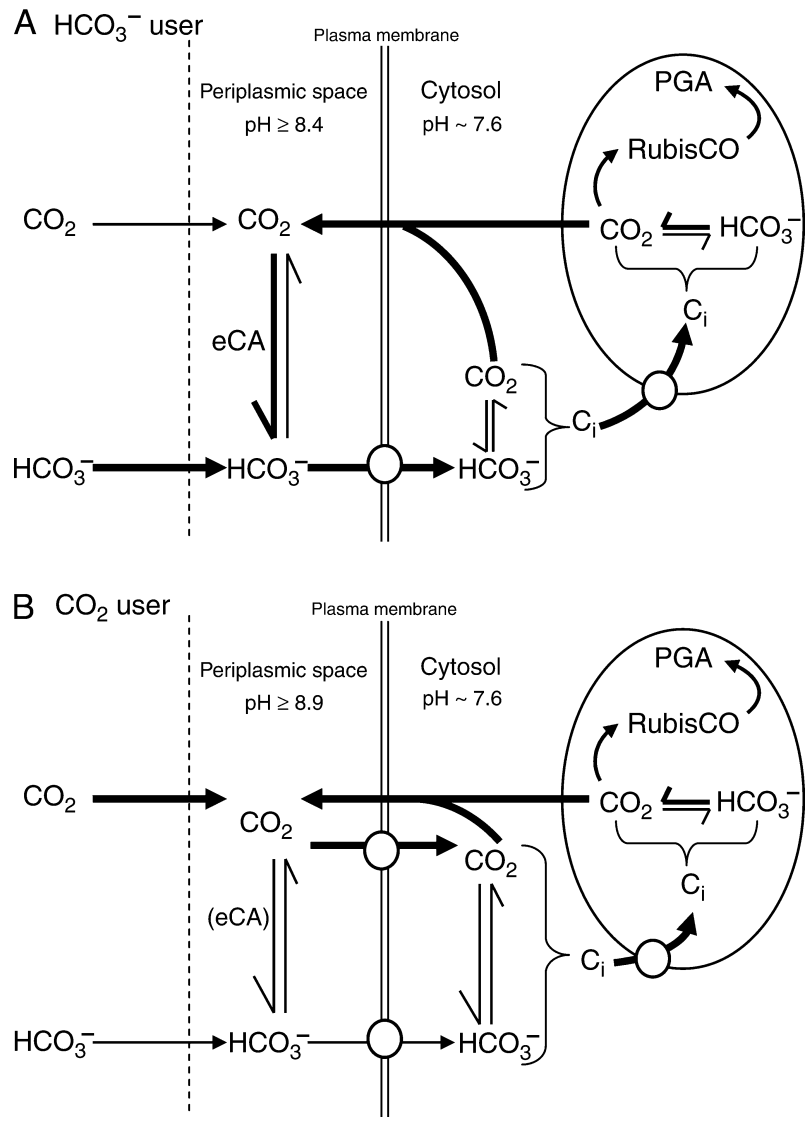

Fig. 5. Model of the $\mathrm{C}_{\mathrm{i}}$-recycling mechanism. The cytosolic $\mathrm{pH}$ is assumed to be approximately 7.6 (Burns and Beardall 1987, Colman and Rotatore 1995) while the $\mathrm{pH}$ in the periplasmic space is assumed to be elevated with respect to the $\mathrm{pH}$ in the bulk media. (A) In ' $\mathrm{HCO}_{3}^{-}$user' as Stellarima stellaris, the $\mathrm{CO}_{2}$ leaking out of the cell would be converted by eCA to $\mathrm{HCO}_{3}^{-}$and subsequently taken up through $\mathrm{HCO}_{3}^{-}$transporters. (B) In ' $\mathrm{CO}_{2}$ user' as Nitzschia navis-varingica, $\mathrm{CO}_{2}$ is prevented from conversion to $\mathrm{HCO}_{3}^{-}$and a disequilibrium in the boundary layer persists. As the $\mathrm{CO}_{2}$ leaking out of the cell remains in the form of $\mathrm{CO}_{2}$ at the cell surface, the probability increases that the $\mathrm{CO}_{2}$ is transported back into the cell through $\mathrm{CO}_{2}$ transport systems. Note that in the chloroplast $\mathrm{CO}_{2}$ is being fixed by RubisCO to produced PGA and sugars.

our data and that of previous investigations, that the presence or absence of eCA allows for a more efficient $\mathrm{C}_{i}$ recycling in ' $\mathrm{HCO}_{3}^{-\prime}$ ' and ' $\mathrm{CO}_{2}$ ' users, respectively.

The physiological role of internally located CA (iCA) is still poorly understood (Sültemeyer 1998) because of the occurrence of multiple CA forms in the cytosol, chloroplast and mitochondria, but there is evidence that iCAs are important components of the CCM (Badger and Price 1994, Sültemeyer 1998, Badger 2003). Prior to our discussion on iCA activities, we would like to point out some of the assumptions underlying the applied approach to estimate iCA activities (Palmqvist et al. 1994). First, it should be noted that the results shown in Fig. 2B do not 
differentiate between the multiple CA forms and their location. Estimates on iCA activities are also dependent on the rate of diffusive influx of ${ }^{18} \mathrm{O}$-labelled $\mathrm{CO}_{2}$ and thus can be altered by the diffusive properties of the cell membrane, intracellular $\mathrm{pH}$ and cell size and shape. In addition, Rost et al. (2003) showed that assessing iCA activities without applying inhibitors for eCA affects the absolute estimates. Because of these uncertainties, the following species comparison should be interpreted with caution.

High iCA levels were expressed in the $\mathrm{CO}_{2}$ user $N$. navis-varingica, while lowest activities were found in the $\mathrm{HCO}_{3}^{-}$user S. stellaris (Fig. 2B). Provided that iCA observed in the latter species is predominantly reflecting CA located in the cytosol, the low activity would prevent the taken up $\mathrm{HCO}_{3}^{-}$from being converted to $\mathrm{CO}_{2}$ and hence it would remain in the form of $\mathrm{HCO}_{3}^{-}$for which cell membranes are highly impermeable. In contrast, high iCA levels in the $\mathrm{CO}_{2}$ user $\mathrm{N}$. navis-varingica enhance the conversion of $\mathrm{CO}_{2}$ to $\mathrm{HCO}_{3}^{-}$in the cytosol. This interpretation of our data is supported by the observation of Price and Badger (1989) that the absence of cytosolic CA activity in Synechococcus, a $\mathrm{HCO}_{3}^{-}$user, is crucial for minimizing $\mathrm{CO}_{2}$ leakage. Consequently, the expression of human CA in the cytosol led to loss of the ability to accumulate internal $C_{i}$. All data together, we propose that the presence or absence of iCA functions to minimize the loss of $\mathrm{CO}_{2}$. Evidence for such a $\mathrm{CO}_{2}$-trapping mechanism is supported by a model study at the level of the chloroplast (Thoms et al. 2001). Further research in marine diatoms is needed to evaluate the potential role of iCA acting as a $\mathrm{CO}_{2}$-trapping mechanism.

\section{Carbon isotope fractionation and leakage}

Carbon isotope fractionation can provide information on modes of carbon uptake in marine phytoplankton (Raven and Johnston 1991, Rost et al. 2002). The interpretation of such data often remains complicated because of a lack of knowledge on processes involved in fractionation. In the present study, the information on the CCM derived by MIMS techniques permits a more thorough analysis of carbon isotope fractionation data. According to the model proposed by Sharkey and Berry (1985), variations in $\varepsilon_{\mathrm{p}}$ are mainly determined by the carbon source taken up and the so-called leakage (L), defined as the ratio of $\mathrm{CO}_{2}$ efflux to the total $\mathrm{C}_{\mathrm{i}}$ uptake:

$$
\varepsilon_{\mathrm{p}}=a \times \varepsilon_{\mathrm{S}}+\mathrm{L} \times \varepsilon_{\mathrm{f}}
$$

In this equation, a represents the fractional contribution of $\mathrm{HCO}_{3}^{-}$to total $\mathrm{C}_{\mathrm{i}}$ uptake and $\varepsilon_{\mathrm{s}}$ is the equilibrium discrimination between $\mathrm{CO}_{2}$ and $\mathrm{HCO}_{3}^{-}$(approximately $-10 \%$ ). The fractionation of the carbon-fixing enzyme RubisCO $\left(\varepsilon_{f}\right)$ is assumed to be $29 \%$. As $\mathrm{HCO}_{3}^{-}$is about $10 \%$ enriched in ${ }^{13} \mathrm{C}$ compared with $\mathrm{CO}_{2}$ (Zeebe and Wolf-Gladrow 2001), an increasing proportion of $\mathrm{HCO}_{3}^{-}$uptake diminishes $\varepsilon_{\mathrm{p}}$, which is defined relative to $\mathrm{CO}_{2}$ as the carbon source. If there is no change in carbon source, $\varepsilon_{\mathrm{p}}$ decreases with decreasing leakage. Based on these considerations, carbon isotope data may provide information on the mode of carbon acquisition and vice versa. In terms of information on the carbon source, only extreme $\varepsilon_{\mathrm{p}}$ values allow precluding one carbon source. If $\varepsilon_{\mathrm{p}}$ is lower than $0 \%, \mathrm{CO}_{2}$ can be excluded as the only carbon source, while $\varepsilon_{\mathrm{p}}$ values higher than $20 \%$ rule out $\mathrm{HCO}_{3}^{-}$as the only carbon source.

In our study, $\varepsilon_{\mathrm{p}}$ values were found to be in between these extreme values, being consistent with both $\mathrm{CO}_{2}$ and $\mathrm{HCO}_{3}^{-}$uptake. Moreover, $\varepsilon_{\mathrm{p}}$ decreases with increasing $\mathrm{pH}$ in all species (Fig. 3). This trend is consistent with results obtained by Burkhardt et al. (1999a, 1999b, 2001), who found $\varepsilon_{\mathrm{p}}$ to increase with decreasing $\mathrm{pH}$ in six marine diatom species. Reasons for this trend will be discussed in the following sections. According to Eqn 7, a higher contribution of $\mathrm{HCO}_{3}^{-}$uptake to net fixation will reduce $\varepsilon_{\mathrm{p}}$. The $15 \%$ higher $\mathrm{HCO}_{3}^{-}$contribution at high $\mathrm{pH}$ observed in N. navis-varingica (Fig. 1) would explain only $1.5 \%$ lower $\varepsilon_{\mathrm{p}}$ values, far less than the observed $6 \%$ difference between $\mathrm{pH}$ treatments. In the other two species, the $\mathrm{HCO}_{3}^{-}$contribution did not change between the $\mathrm{pH}$ levels (Fig. 1). Consequently, most of the variation in $\varepsilon_{p}$ observed in all investigated species has to result from changes in leakage. Taking the measured $\varepsilon_{\mathrm{P}}$ (Fig. 3) as well as the estimates of a obtained through the $\mathrm{C}_{\mathrm{i}}$ flux assays, leakage was calculated according to Eqn 7 (Fig. 6). The calculated values decreased with increasing $\mathrm{pH}$ in all species, but between species, large differences were found. Highest values were calculated for $S$. stellaris ( 0.67 and 0.73 at high and low $\mathrm{pH}$, respectively) and lowest values for $\mathrm{N}$. navis-varingica (0.22 and 0.39 at high and low $\mathrm{pH}$, respectively).

Because the calculated leakage is based on the assumption that the cell consists of a single compartment, an assumption obviously not matching the real structure of eukaryotic cells, it should be pointed out that the calculated leakage may only serve as an approximation of the maximal possible leakage. Any internal $C_{i}$ cycling at the level of the chloroplast will decrease the leakage and subsequently $\varepsilon_{\mathrm{p}}$ (Schulz et al. 2007). Another shortcoming of the model by Sharkey and Berry (1985) is the assumption of a complete equilibrium of the carbonate system. According to Raven (1997), $\mathrm{HCO}_{3}^{-}$is considered as the carbon source that enters 


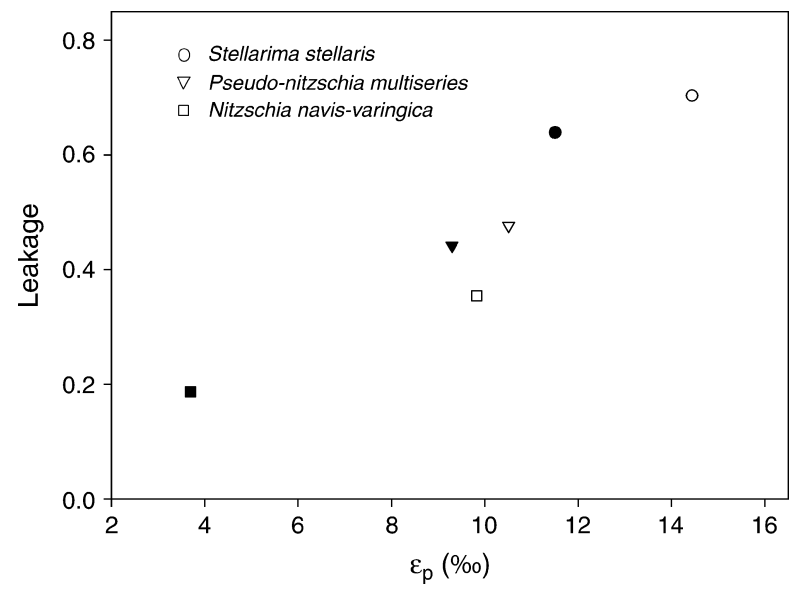

Fig. 6. Leakage of the cells as a function of $\varepsilon_{\mathrm{p}}$, calculated according to Sharkey and Berry (1985). Closed and open symbols represent high and low $\mathrm{pH}$, respectively.

the acidic thylakoid lumen $(\mathrm{pH}=5)$. For such a low $\mathrm{pH}$, the spontaneous rate of $\mathrm{HCO}_{3}^{-}$to $\mathrm{CO}_{2}$ conversion is sufficient to explain the observed C-fixation by RubisCO (Thoms et al. 2001). Subsequently, CA activity inside the thylakoid lumen is not necessary as previously suggested by Raven (1997). Considering that the uncatalysed conversion of $\mathrm{HCO}_{3}^{-}$to $\mathrm{CO}_{2}$ accounts for $22 \%$ (O'Leary et al. 1992), the $\mathrm{CO}_{2}$ supply at the site of RubisCO in the thylakoid lumen would be isotopically lighter and hence shift $\varepsilon_{\mathrm{p}}$ to higher values. However, the latter assumes that there is no back conversion of $\mathrm{CO}_{2}$ to $\mathrm{HCO}_{3}^{-}$in the lumen, i.e. a complete non-equilibrium exists. In order to estimate the actual state of the carbonate system in the lumen, a detailed calculation is essential (Thoms et al. in preparation).

We also employed the MIMS to get estimates on leakage following the approach by Badger et al. (1994). Leakage was relatively low in all three species and diminished only in $\mathrm{N}$. navis-varingica with increasing $\mathrm{pH}$ (Fig. 4). It should be noted here that these calculations are based on several assumptions, for instance, that the rate of diffusive $\mathrm{CO}_{2}$ efflux is well represented during the first seconds of the subsequent dark phase. This approach may underestimate the real $C_{i}$ efflux because of re-fixation of $\mathrm{CO}_{2}$ by RubisCO in the dark (Badger et al. 1994, Rost et al. 2006b). Furthermore, a prerequisite for the application of this approach is the absence of eCA activity, which we ensured by the addition the eCA inhibitor DBS. Because eCA might act as a $\mathrm{C}_{\mathrm{i}}$-recycling mechanism, the inhibition of this enzyme may have an effect on the $\mathrm{CO}_{2}$ efflux estimates. This underlines that new approaches are required to obtain better estimates on the important aspect of leakage.

\section{Relationship between $\mathrm{pH}$, carbon acquisition and DA production}

It has been reported that higher DA production occurred at elevated $\mathrm{pH}$ in different strains of $P$. multiseries (Lundholm et al. 2004). To explain this effect, it has been proposed that toxin production could be induced by carbon limitation with increasing $\mathrm{pH}$ (Lundholm et al. 2004). In our experiments, as expected, DA was produced in the two potentially toxic species $P$. multiseries and $N$. navis-varingica, while no production was found in the non-toxic species $S$. stellaris. The content of DA increased significantly in both toxic species with increasing $\mathrm{pH}$ (Table 3) but was most pronounced for P. multiseries, where the increase in cellular DA content was more than 70 -fold. This finding confirms the observation by Lundholm et al. (2004) that increasing $\mathrm{pH}$ induces higher DA levels. With respect to rather low values of $K_{1 / 2}$ for photosynthesis in P. multiseries and N. navis-varingica (Table 2), significant DIC limitation is not indicated even under high $\mathrm{pH}$. Consequently, the suggested relationship between DA and carbon acquisition/ $C_{i}$ limitation cannot be confirmed. It is hence likely that $\mathrm{pH}$ triggers the DA production in another way than by altering the carbonate chemistry. As such, external $\mathrm{pH}$ could affect internal $\mathrm{pH}$, which in turn could alter many processes that are not associated to carbon acquisition or limitation (Hansen et al. 2007). The importance of $\mathrm{pH}$ should therefore be considered in future monitoring programmes for harmful phytoplankton species.

\section{Ecological implications and conclusions}

In view of the ongoing acidification of the oceans (WolfGladrow et al. 1999, Orr et al. 2005) as well as elevated $\mathrm{pH}$ during blooms (Hansen 2002), the observed differences in CCM efficiency and regulation of the investigated diatoms may play an important role for the dominance of certain diatom species (Tortell et al. 2002, Rost et al. 2003). It is a common notion that species being able to use the large $\mathrm{HCO}_{3}^{-}$pool may have a competitive advantage over those that rely on $\mathrm{CO}_{2}$ and thus may be less sensitive to variations in $\mathrm{pH}$ (Hansen 2002, Korb et al. 1997, Nimer et al. 1997, Tortell and Morel 2002). Consequently, elevated pH should especially favour species that prefer $\mathrm{HCO}_{3}^{-}$as their carbon source. However, the $\mathrm{pH}$ limit for growth for the predominant $\mathrm{HCO}_{3}^{-}$user $S$. stellaris was already attained at $\mathrm{pH} 8.8$ (Lundholm, unpublished data) although most of the DIC was present in the form of its preferred carbon source. S. costatum showed a strong preference for $\mathrm{HCO}_{3}^{-}$under high pH (Rost et al. 2003), but growth was already affected above pH 8.5 (Schmidt and Hansen 
2001). In contrast, the $\mathrm{CO}_{2}$ user $N$. navis-varingica grew up to $\mathrm{pH}$ values of 10 (Lundholm, unpublished data, Kotaki et al. 2000). Similarly, the $\mathrm{CO}_{2}$ user $P$. tricornutum (Burkhardt et al. 2001) can maintain growth up to $\mathrm{pH} 10$ (Goldman et al. 1982, Humphrey 1975). Such high pH limits for growth in $\mathrm{CO}_{2}$ users call into question the common notion that ' $\mathrm{HCO}_{3}^{-}$users' have a competitive advantage over $\mathrm{CO}_{2}$ users. According to our data and those of previous investigations, ' $\mathrm{HCO}_{3}^{-}$users' are as sensitive as $\mathrm{CO}_{2}$ users with regard to their $\mathrm{pH} / \mathrm{CO}_{2}$ dependence of growth. This finding is surprising because the $\mathrm{CO}_{2}$ availability is strongly reduced at high $\mathrm{pH}$ and thus $\mathrm{CO}_{2}$ users should be more prone to elevated $\mathrm{pH}$. The underlying mechanisms are unclear but may point to species-specific differences in leakage (Rost et al. 2006b) as well as direct effects of pH (Hansen et al. 2007). The latter could have impact on the ion balance of the cell and hence transporter functioning and energy requirements.

Bloom-forming phytoplankton species should be especially dependent on an efficient and regulated CCM as they maintain high growth rates even under bloom conditions when $\mathrm{pH}$ rises because of photosynthetic carbon consumption (e.g. Elzenga et al. 2000, Rost et al. 2003). The bloom-forming species $P$. multiseries obtained approximately $30 \%$ higher $V_{\max }$ of photosynthetic $\mathrm{O}_{2}$ evolution compared with the non-bloom-forming species (Table 2). Considering that $\mathrm{CO}_{2}$ concentrations may be as low as $5 \mu \mathrm{mol} \mathrm{I}{ }^{-1}$ towards the end of a bloom, the high $\mathrm{C}_{\mathrm{i}}$ affinity observed in bloom-forming species like $P$. multiseries directly translates to higher rates of carbon fixation. Moreover, bloom-forming diatom species tend to be more flexible in the use of different carbon sources (Fig. 1). These abilities may provide a competitive advantage, especially under changing conditions as they occur during a bloom. According to our results, the diatoms as group differ strongly in their mode of carbon acquisition and hence generalizations cannot be made.

\section{References}

Amoroso G, Sültemeyer D, Thyssen C, Fock HP (1998) Uptake of $\mathrm{HCO}_{3}^{-}$and $\mathrm{CO}_{2}$ in cells and chloroplasts from the microalgae Chlamydomonas reinhardtii and Dunaliella tertiolecta. Plant Physiol 116: 193-201

Badger MR, Price GD (1989) Carbonic anhydrase activity associated with the cyanobacterium Synechococcus PCC7942. Plant Physiol 89: 51-60

Badger MR, Price GD (1994) The role of carbonic anhydrase in photosynthesis. Annu Rev Plant Physiol Plant Mol Biol 45: 369-392

Badger MR, Palmqvist K, Yu J-W (1994) Measurement of $\mathrm{CO}_{2}$ and $\mathrm{HCO}_{3}^{-}$fluxes in cyanobacteria and microalgae during steady-state photosynthesis. Physiol Plant 90: 529-536
Badger MR, Andrews TJ, Whitney SM, Ludwig M, Yellowlees DC, Leggat W, Price GD (1998) The diversity and coevolution of Rubisco, plastids, pyrenoids, and chloroplast-based $\mathrm{CO}_{2}$-concentrating mechanisms in algae. Can J Bot 76: 1052-1071

Badger MR (2003) The role of carbonic anhydrases in photosynthetic $\mathrm{CO}_{2}$ concentrating mechanisms. Photosynth Res 77: 83-94

Bates SS, Garrison DL, Horner RA (1998) Bloom dynamics and physiology of domoic-acid producing Pseudonitzschia species. In: Anderson DM, Cembella AD, Hallegraeff GM (eds) Physiological Ecology of Harmful Algal Blooms. Springer, Berlin, pp 267-292

Berman-Frank I, Zohary T, Erez J, Dubinsky Z (1994) $\mathrm{CO}_{2}$ availability, carbonic anhydrase and the annual dinoflagellate bloom in Lake Kinneret. Limnol Oceanogr 39: 1822-1834

Brewer PG, Bradshow AL, Williams RT (1986) Measurement of total carbon dioxide and alkalinity in the North Atlantic Ocean in 1981. In: Trabalka JR, Reichle DE (eds) The Changing Carbon Cycle - A Global Analysis. Springer, New York, pp 358-381

Burkhardt S, Riebesell U, Zondervan I (1999a) Effects of growth rate, $\mathrm{CO}_{2}$ concentration, cell size on the stable carbon isotope fractionation in marine phytoplankton. Geochim Cosmochim Acta 63: 3729-3741

Burkhardt S, Riebesell U, Zondervan I (1999b) Stable carbon isotope fractionation by marine phytoplankton in response to daylength, growth rate, and $\mathrm{CO}_{2}$ availability. Mar Ecol Prog Ser 184: 31-41

Burkhardt S, Amoroso G, Riebesell U, Sültemeyer D (2001) $\mathrm{CO}_{2}$ and $\mathrm{HCO}_{3}^{-}$uptake in marine diatoms acclimated to different $\mathrm{CO}_{2}$ concentrations. Limnol Oceanogr 46: 1378-1391

Burns BD, Beardall J (1987) Utilization of inorganic carbon acquisition by marine microalgae. J Exp Mar Bio Ecol 107: 75-86

Colman B, Rotatore C (1995) Photosynthetic inorganic carbon uptake and accumulation in two marine diatoms. Plant Cell Environ 18: 919-924

Dickson AG, Millero FJ (1987) A comparison of the equilibrium constants for the dissociation of carbonic acid in seawater media. Deep Sea Res 34: 1733-1743

Elzenga JTM, Prins HBA, Stefels J (2000) The role of extracellular carbonic anhydrase activity in inorganic carbon utilization of Phaeocystis globosa (Prymnesiophyceae): a comparison with other marine algae using the isotope disequilibrium technique. Limnol Oceanogr 45: 372-380

Freeman KH, Hayes JM (1992) Fractionation of carbon isotopes by phytoplankton and estimates of ancient $\mathrm{CO}_{2}$ levels. Global Biogeochem Cycles 6: 185-198

Giordano M, Beardall J, Raven JA (2005) $\mathrm{CO}_{2}$ concentrating mechanisms in algae: mechanisms, environmental 
modulation, and evolution. Annu Rev Plant Biol 56: 99-131

Goldman JC, Riley CB, Dennett MR (1982) The effect of pH in intensive microalgal cultures. II. Species competition.

J Exp Mar Biol Ecol 57: 15-24

Gran G (1952) Determinations of the equivalence point in potentiometric titrations of seawater with hydrochloric acid. Oceanol Acta 5: 209-218

Guillard RRL, Ryther JH (1962) Studies of marine planktonic diatoms. Can J Microbiol 8: 229-239

Hansen PJ (2002) Effect of high $\mathrm{pH}$ on the growth and survival of marine phytoplankton: implications for species succession. Aquat Microb Ecol 28: 279-288

Hansen PJ, Lundholm N, Rost B (2007) Growth limitation in marine red-tide dinoflagellates: effects of $\mathrm{pH}$ versus inorganic carbon availability. Mar Ecol Prog Ser 334: 63-71

Hinga KR (2002) Effects of pH on coastal marine phytoplankton. Mar Ecol Prog Ser 238: 281-300

Humphrey GF (1975) The photosynthesis: respiration ratio of some unicellular marine algae. J Exp Mar Biol Ecol 18: 111-119

Intergovernmental Panel on Climate Change (2007) Working Group I Report "The Physical Science Basis". Available at http://ipcc-wg1.ucar.edu/wg1/wg1-report.html

Korb RE, Saville PJ, Johnston AM, Raven JA (1997) Sources for inorganic carbon for photosynthesis by three marine species of marine diatom. J Phycol 33: 433-440

Kotaki Y, Koike K, Yoshida M, Thuoc CV, Huyen NTM, Hoi NC, Fukoyo Y, Kodama M (2000) Domoic acid production in Nitzschia sp. (Bacillariophyceae) isolated from a shrimp-culture pond in Do Son, Vietnam. J Phycol 36: 1057-1060

Lewis E, Wallace DWR (1998) Program Developed for $\mathrm{CO}_{2}$ System Calculations. ORNL/CDIAC-105. Carbon Dioxide Information Analysis Center. Oak Ridge National Laboratory, U.S. Department of Energy

Lundholm N, Hansen PJ, Kotaki Y (2004) Effect of pH on growth and domoic acid production by potentially toxic diatoms of the genera Pseudo-nitzschia and Nitzschia. Mar Ecol Prog Ser 273: 1-15

Matsuda Y, Colman B (1995) Induction of $\mathrm{CO}_{2}$ and bicarbonate transport in the green alga Chlorella ellipsoidea. I. Time course of induction of the two systems. Plant Physiol 108: 247-252

Mehrbach C, Culberson C, Hawley J, Pytkovicz R (1973) Measurement of the apparent dissociation constants of carbonic acid in seawater at atmospheric pressure. Limnol Oceanogr 18: 897-907

Mitchell C, Beardall J (1996) Inorganic carbon uptake by an Antarctic sea-ice diatom, Nitzschia frigida. Polar Biol 16: 95-99

Mook WG $(1986){ }^{13} \mathrm{C}$ in atmospheric $\mathrm{CO}_{2}$. Neth J Sea Res 20: 211-223
Nelson DM, Tréguer P, Brzezinski MA, Leynaert A, Quéginer B (1995) Production and dissolution of biogenic silica in the ocean: Revised global estimates, comparison with regional data and relationship to biogenic sedimentation. Global Biogeochem Cycles 9: 359-372

Nimer, NA, Iglesias-Rodriguez MD, Merrett MJ (1997) Bicarbonate utilization by marine phytoplankton species. J Phycol 33: 625-631

O'Leary MH, Madhavan S, Paneth P (1992) Physical and chemical basis of carbon isotope fractionation in plants. Plant Cell Environ 15: 1099-1104

Orr JC, Fabry VJ, Aumont O, Bopp L, Doney SC, Feely RA, Gnanadesikan A, Gruber N, Ishida A, Joos F, Key RM, Lindsay K, Maier-Reimer E, Matear R, Monfray P, Mouchet A, Najjar RG, Plattner G-K, Rodgers KB, Sabine CL, Sarmiento JL, Schlitzer R, Slater RD, Totterdell IJ, Weirig M-F, Yamanaka Y, Yool A (2005) Anthropogenic ocean acidification over the twenty-first century and its impact on calcifying organisms. Nature 437: 681-686

Palmqvist K, Yu J-W, Badger MR (1994) Carbonic anhydrase activity and inorganic carbon fluxes in low- and high- $\mathrm{C}_{\mathrm{i}}$ cells of Chlamydomonas reinhardtii and Scenedesmus obliquus. Physiol Plant 90: 537-547

Price GD, Badger MR (1989) Expression of human carbonic anhydrase in the cyanobacterium Synechococcus PCC7942 creates a high $\mathrm{CO}_{2}$-requiring phenotype. Evidence for a central role for carboxysomes in the $\mathrm{CO}_{2}$ concentrating mechanism. Plant Physiol 91: 505-513

Raven JA (1997) $\mathrm{CO}_{2}$ concentrating mechanisms: a direct role for thylakoid lumen acidification? Plant Cell Environ 20: 147-154

Raven JA, Lucas WJ (1985) Energy costs of carbon acquisition. In: Lucas WJ, Berry JA (eds) Inorganic carbon uptake by aquatic photosynthetic organisms. American Society of Plant Physiologists, Rockville, MD, pp 305-324

Raven JA, Johnston AM (1991) Mechanisms of inorganic carbon acquisition in marine phytoplankton and their implications for the use of other resources. Limnol Oceanogr 36: 1701-1714

Rost B, Zondervan I, Riebesell U (2002) Light-dependant carbon isotope fractionation in the coccolithophorid Emiliania huxleyi. Limnol Oceanogr 47: 120-128

Rost B, Riebesell U, Burkhardt S, Sültemeyer D (2003) Carbon acquisition of bloom-forming marine phytoplankton. Limnol Oceanogr 48: 55-67

Rost B, Riebesell U, Sültemeyer D (2006a) Carbon acquisition of marine phytoplankton. Effect of photoperiod length. Limnol Oceanogr 51: 12-20

Rost B, Richter K-U, Riebesell U, Hansen PJ (2006b) Inorganic carbon acquisition in red tide dinoflagellates. Plant Cell Environ 29: 810-822

Rost B, Kranz S, Richter K-U, Tortell P (2007) Isotope disequilibrium and mass spectrometric studies of inorganic 
carbon acquisition by phytoplankton. Limnol Oceanogr Methods 5: 328-337

Rotatore C, Colman B, Kuzma M (1995) The active uptake of carbon dioxide by the marine diatoms Phaeodactylum tricornutum and Cyclotella sp. Plant Cell Environ 18: 913-918

Schmidt LE, Hansen PJ (2001) Allelopathy in the prymnesiophyte Chrysochromulina polylepis: effect of cell concentration, growth phase and $\mathrm{pH}$. Mar Ecol Prog Ser 216: $67-81$

Schulz KG, Rost B, Burkhardt S, Riebesell U, Thoms S, Wolf-Gladrow DA (2007) The effect of iron availability on the regulation of inorganic carbon acquisition in the coccolithophore Emiliania huxleyi and the significance of cellular compartmentation for stable carbon isotope fractionation. Geochim Cosmochim Acta 71: 5301-5312

Sharkey TD, Berry JA (1985) Carbon isotope fractionation of algae influenced by an inducible $\mathrm{CO}_{2}$ concentrating mechanism. In: Lucas WJ, Berry JA (eds) Inorganic carbon uptake by aquatic photosynthetic organisms. American Society of Plant Physiologists, Rockville, MD, pp 389-401

Silverman DN (1982) Carbonic anhydrase. Oxygen-18 exchange catalyzed by an enzyme with rate contributing proton-transfer steps. Methods Enzymol 87: 732-752

Sterling D, Reithmeier RAF, Casey JF (2001) A transport metabolon. J Biol Chem 276: 47886-47894

Sültemeyer D (1998) Carbonic anhydrase in eukaryotic algae: characterization, regulation, and possible function during photosynthesis. Can J Bot 76: 962-972
Thoms S, Pahlow M, Wolf-Gladrow DA (2001) Model of the carbon concentrating mechanism in chloroplasts of eukaryotic algae. J Theor Biol 208: 295-313

Tortell PD, Morel FMM (2002) Sources of inorganic carbon for phytoplankton in the eastern Subtropical and Equatorial Pacific Ocean. Limnol Oceanogr 47: 1012-1022

Tortell PD, DiTullio GR, Sigman DM, Morel FMM (2002) $\mathrm{CO}_{2}$ effects on taxonomic composition and nutrient utilization in an Equatorial Pacific phytoplankton assemblage. Mar Ecol Prog Ser 236: 37-43

Tortell PD, Martin CL, Corkum ME (2006) Inorganic carbon uptake and intracellular assimilation by subarctic Pacific assemblages. Limnol Oceanogr 51: 2102-2110

Wilbur KM, Anderson NG (1948) Electrometric and colometric determination of carbonic anhydrase. J Biol Chem 176: 147-154

Wolf-Gladrow DA, Riebesell U (1997) Diffusion and reaction in the vicinity of plankton: a refined model for inorganic carbon transport. Mar Chem 59: 17-34

Wolf-Gladrow DA, Riebesell U, Burkhardt S, Bijma J (1999) Direct effects of $\mathrm{CO}_{2}$ concentration on growth and isotopic composition of marine phytoplankton. Tellus 51: 461-476

Zeebe RE, Wolf-Gladrow DA (2001) $\mathrm{CO}_{2}$ in Seawater: Equilibrium, Kinetics, Isotopes. Elsevier Science, Amsterdam

Zhang J, Quay PD, Wilbur DO (1995) Carbon isotope fractionation during gas-water exchange and dissolution of $\mathrm{CO}_{2}$. Geochim Cosmochim Acta 59: 107-114 